LENTERA PENDIDIKAN, EDISI X, NO. 2, DESEMBER 2007 (153-172)

\title{
KRITIK TERHADAP PANDANGAN SIGMUND FREUD: Agama dan Implikasinya terhadap Pendidikan
}

\author{
Oleh: Abdul Rahman Barakatu
}

\begin{abstract}
Freud considers that motivation source of religion behavior is sexual libido. He also states that religion is illusion, its adherent ails neurosis and childish, even he states that believing in God is useless action which handicaps the development of man personality. Even though, he explains the analysis of super ego, but his opinion has implication which ignores the religion education such as adhered by the Western scholars, especially in 19 century. This case invites critics which asking the validity of Freud's opinion and it is debated from point of view the use of methodology, philosophical thought by supporting empirical reality, and the content of Freud's comment about religion.
\end{abstract}

KEYWORDS: Verifikasi, prediksi, suprarasional, katarsis, fitrah

URAIAN yang terdapat dalam jurnal Lentera Akademika Edisi IV tahun 2002 mengungkapkan pandangan Sigmund Freud yang sangat kelam mengenai agama. Freud menganggap agama sebagai ilusi, penganutnya mengidap neurosis dan bersifat infantilis. Pandangan Freud sekaligus menyatakan bahwa agama adalah sesuatu yang sia-sia, tidak berguna, dan merusak perkembangan kepribadian manusia karena keyakinan beragama hanya merupakan proses sublimasi dari konflik yang terjadi pada masa kanak-kanak antara orangtua dan anak yang disebutnya sebagai fenomena Oedipus Complex. ${ }^{1}$

Pandangan Freud menurunkan derajat agama sekaligus menghancurkan martabat penganutnya. Padahal, kenyataan menunjukkan bahwa kehidupan beragama semakin menjadi intens dan menggejala pertumbuhannya. Hal ini diungkapkan oleh Naisbit (1990) dalam bukunya "The New Direction for the 1900's: Mega Trend 2000".2 Selanjutnya Princeton Religion Research Center juga mengungkapkan hasil penelitian bahwa $96 \%$ orang yang hidup di Amerika percaya kepada Tuhan, di atas $90 \%$ bersembahyang, $69 \%$ menjadi anggota persekutuan gereja, dan $43 \%$ mengunjungi gereja, sinagoge, dan kuil. ${ }^{3}$

Agama merupakan hajat hidup manusia yang vital. Posisi moral agama memainkan peran yang sangat menentukan untuk mengarahkan 
perkembangan ilmu pengetahuan dan teknologi sehingga kehidupan manusia tidak mengalami kehancuran. Einstein, seorang fisikawan terkenal, membuat pernyataan bahwa: "Science without religion is blind and religion without science is lame." Kehidupan manusia akan terasa hampa tidak bermakna tanpa mendapatkan tuntunan cahaya ajaran ilahi yang termuat dalam agama. Frankl mengungkapkan dalam karyanya yang berjudul "Man Search Himself" mengenai pencarian kehidupan bermakna. ${ }^{4}$

Tidaklah mengherankan bila kemudian pandangan Freud mengenai agama menuai kritik. Artikel ini akan mengungkapkan ulasan kritis yang ditujukan kepada penggunaan metodologi, pemikiran filosofis, dan isi pernyataan Freud mengenai agama dengan ilustrasi dukungan data empiris yang dikaitkan dengan implikasinya dalam dunia pendidikan. Ulasan ini diperlukan untuk meluruskan kembali posisi agama dan fungsinya bagi kemanusiaan.

\section{CACAT METODOLOGIS DAN PEMIKIRAN FILOSOFIS}

Rasjidi mengisyaratkan untuk berhati-hati dengan pandangan Freud karena sifat uraian psikologi yang biasanya sangat meyakinkan dan menarik untuk ditelaah. Manusia akan terbuai dan menganutnya sebagai suatu kebenaran ilmiah yang mutlak jika tidak menganalisisnya secara kritis dan berusaha memahaminya secara mendalam. Rasjidi dalam kritiknya menyatakan bahwa contoh-contoh kehidupan agamis yang dikemukakan oleh Freud hanyalah orang-orang primitif dan orang-orang patologis. Contoh-contoh kehidupan keagamaan yang dikemukakan Freud tidak pernah menyentuh orang yang terkenal agamis dan ilmuwan seperti Pascal Reinhold Neibuhr, William Temple, Karel Barth yang sezaman dengan Freud. ${ }^{5}$

Pernyataan Rasyidi menunjukkan bahwa Freud menggunakan cara pengambilan sampel yang tidak mencerminkan representasi dari manusia yang beragama. Dari sisi metodologis, hal ini merupakan titik lemah penarikan inferensi pandangan Freud mengenai agama. Freud hanya meneliti pasien-pasien yang menderita penyakit mental atau pasien yang menghalami kegoncangan jiwa seperti frustrasi, anxiety, depresi, neurosis, dan psikotik. Generalisasi yang ditarik dari hasil pengamatannya terhadap orang-orang yang mengalami gangguan mental menyebabkan Freud berkesimpulan bahwa agama adalah ilusi dan neurosis yang mengancam kehidupan manusia.

Metode yang ditempuh Freud dalam menarik konklusi sangat naif, sederhana, dan spekulatif berdasarkan hasil renungannya. Djamaluddin Ancok \& Fuat Nashori Suroso mengemukakan bahwa konklusi Freud 
belum didasarkan pada premis yang valid, karena hanya mewakili orang yang sakit dan penuh konflik. Kekeliruan yang terjadi pada Freud sama dengan psikolog lainnya yang mudah mereduksi fenomena-fenomena yang tampak dalam kehidupan manusia. ${ }^{6}$

Uraian Freud mengenai agama mengesankan pengagumnya yang seolah-olah mendapatkan wahyu yang membukakan mata terhadap kebenaran baru yang semula tersembunyi. Namun demikian, Popper, seorang filosof, meragukan status ilmiah teori Freud. Menurutnya, teori Freud seperti dengan teori Marx yang mencari pembenaran teori. Keduanya terus menerus berusaha menemukan 'verifikasi' bagi teori kesayangannya. Berbeda dengan Einstein mencari eksperimen-eksperimen krusial yang kesesuaiannya dengan ramalannya tidak mengukuhkan teorinya secara positif, sementara ketidaksesuaiannya, seperti yang dia tetapkan, akan menfalsifikasikan teorinya. ${ }^{7}$

Verifikasi merupakan salah satu cara untuk menguji satu teori. Pemikiran filsafat menggunakan dua metode untuk melakukan verifikasi yakni observasi dan hukum kontradiksi. Suatu pernyataan yang maknanya dapat diuji dengan pengalaman dan dapat diulangi baik oleh yang mempergunakan pernyataan maupun oleh orang lain, pada prinsipnya dapat dilakukan verifikasi. Jika pernyataan itu lulus dalam ujian pengalaman, maka pernyataan itu dikukuhkan, meskipun tidak sepenuhnya terbukti benar. Penalaran berdasarkan kontradiksi menunjukkan kesesatan pernyataan yang dipersoalkan ialah karena bertentangan dengan dirinya, atau mengakibatkan pertentangan dengan pernyataan-pernyataan lain yang telah ditetapkan dengan baik. ${ }^{8}$

Bila teori Freud tentang agama diverifikasi, maka akan sangat bertentangan dengan realitas empiris. Penggunaan observasi dan hukum kontradiksi terhadap pernyataan Freud bahwa agama adalah ilusi, penganutnya mengidap neurosis dan infantilis tidak terbukti sebab agama pada hakekatnya merupakan satu realitas yang membangun kemanusiaan dengan bukti-bukti kuat yang terlihat dalam sejarah peradaban manusia. Istana Al-Hambra, Taj Mahal, Borobudur, dan Kathederal Roma merupakan karya agung yang dihasilkan oleh dorongan motivasi beragama dari manusia-manusia yang mempunyai appresiasi agama yang intens. Penghayatan agama yang mendalam mengantar manusia penganutnya berkarya besar dan monumental. Karya-karya agung tersebut bukan hasil dari orang yang menderita penyakit neurosis. Bukti empiris sejarah ini sekaligus menolak anggapan Freud bahwa agama merupakan hal yang sia-sia dalam kehidupan manusia.

Pandangan Freud mengenai agama sebagai ilusi dan sia-sia mempunyai kelemahan karena tidak mempunyai daya prediksi yang ampuh. 
Salah satu persyaratan metodologis dari suatu teori yang baik adalah kemampuannya untuk memprediksi sebelumnya apa yang akan terjadi. ${ }^{9}$ Suatu teori psikologi bukan hanya membawa ilmuwan pada pengajuan pertanyaan-pertanyaan yang mungkin akan berguna, melainkan juga teori itu dapat memperlihatkan apa yang dapat diharapkannya untuk ditemukan, bila ia telah melakukan eksperimen atau pengamatan. ${ }^{10}$

Andaikan teori Freud mengenai agama mempunyai prediksi yang tepat dan dapat dipercaya, maka dapat dikatakan bahwa tidak akan ada lagi penemuan-penemuan besar dan karya-karya mengagumkan dari orang yang beragama. Orang gila yang diliputi dengan kehidupan kejiwaan yang penuh ilusi tidak akan mampu untuk menghasilkan suatu karya kemanusiaan. Namun, sejarah membuktikan bahwa agama mempunyai sumbangan yang sangat besar bagi perkembangan dan transformasi peradaban. Orang-orang muslim mengambil manfaat dari Hellenisme, sehingga mereka melahirkan peradaban tinggi yang berpusat di Andalusia dan Bagdad. Kejayaan kebudayaan Islam itu berlangsung sekitar delapan abad; ...Begitu juga dengan Renaissance Italia, yang didasari semangat untuk menghidupkan kembali kejayaan Yunani Klasik, pada dasarnya adalah hasil perkawinan antara elemen-elemen kebudayaan Yunani dan Nasrani. Yunani Klasik, Romawi, Islam, Renaissance merupakan tonggaktonggak sejarah peradaban yang mengagumkan yang selalu dikenang sampai sekarang. ${ }^{11}$

Peneltian Clinibel menunjukkan bahwa agama mempunyai kontribusi yang unik terhadap perkembangan psikologis dan pemeliharaan fungsi kesehatan mental manusia, yakni: 1) agama memberikan suatu periode pembaruan keyakinan dasar, 2) agama mengembangkan perasaan keterikatan secara horizontal dan vertikal, 3) agama memberikan filsafat hidup yang bergairah, 4) agama membantu manusia mengadakan transendensi diri, 5) agama memberi prosedur untuk mengatasi krisis kehidupan, dan 6) agama membantu mengembangkan pertumbuhan pribadi dan perkembangan perubahan sosial. ${ }^{12}$ Hasil Penelitian ini menolak pernyataan Freud.

Pada dasarnya, pandangan Freud berisi kritikan serta sinisme terhadap agama. Creel menyatakan bahwa "... Sigmund Freud, one of the twentieth centuries most trenchant critics of religion." 13 Freud berusaha menjustifikasi dan memverifikasi pendapatnya mengenai agama melalui Oedipus Complex dan Totemisme. Freud ingin meyakinkan manusia bahwa tuhan yang menjadi dasar utama bagi setiap agama hanya merupakan buatan akal manusia saja atau ilusi. Sikap Freud ini dapat dimaklumi karena pada abad pertengahan sebagian penguasa agama pernah mema- 
sung perkembangan kemajuan ilmu pengetahuan. Walaupun begitu, prasangka tidak dapat dijadikan sebagai suatu landasan generalisasi.

Bukti-bukti ilmiah menolak asumsi Freud mengenai agama dan Tuhan. Salah satu di antaranya adalah ketika Laplace menyerahkan kepada Napoleon sebuah buku karyanya yang menjelaskan gerakan bintangbintang dan benda-benda angkasa, Napoleon bertanya mengapa tuhan tidak disebut dalam buku itu. Laplace menjawab: "Saya tidak memerlukan hipotesis itu." Maksudnya, gagasan tentang tuhan tidak diperlukan lagi bila kita ingin melukiskan ketertiban serta keteraturan angkasa raya. Sebab hukum-hukum ilmu pengetahuan telah mencukupi. Ilmu pengetahuan telah mendapatkan suatu kewibawaan yang hampir-hampir mustahil dapat diganggu-gugat untuk menjadi bukti adanya Tuhan. ${ }^{14}$ Manusia dianugerahi kesadaran tentang dimensi pengatur yang disebut dengan transendensi yakni rasa bersandar kepada Tuhan Maha Pencipta. ${ }^{15}$

Cara berpikir menurut logika mengantar manusia menetapkan bahwa sesuatu yang ada pasti mempunyai pencipta. Sesuatu tidak akan berwujud tanpa pencipta. Penetapan bahwa alam ini ada dengan sendirinya merupakan suatu hal yang mustahil dan ditolak menurut rasio. Pemikiran ini berujung kepada suatu kesimpulan tentang adanya "Causa prima" (penyebab utama atau pencipta utama) yaitu Tuhan. Perjalanan planet dan bintang-bintang yang teratur dan tertib memenuhi alam jagat raya dan kaitannya dengan kehidupan alam makrokosmos tidak mungkin terjadi tanpa satu pengatur yang maha hebat yang memiliki kekuasan mutlak yang tidak ada lagi kekuasaan yang dapat melampauiNya. Dalam hal pemikiran religius, Cassirer berkomentar bahwa:

\footnotetext{
Pemikiran religius sebenarnya tidaklah perlu dipertentangkan dengan pemikiran rasional atau pemikiran filosofis. Salah satu tugas pokok filsafat abad pertengahan adalah menentukan hubungan antara kedua cara berpikir itu. Dalam puncak sistem skolastik tampak masalah itu terpecahkan. Menurut Thomas Aquinas, kebenaran religius bersifat suprarasional dan supranatural, tetapi tidak bisa disebut 'irrasional." Hanya dengan rasio saja kita tidak dapat menembus misteri iman. Namun, misteri-misteri itu bukannya bertentangan dengan rasio, melainkan melengkapi dan menyempurnakan rasio. 16
}

Kritik terhadap pandangan Freud mengenai agama mempunyai dasar yang cukup kuat untuk menggugat keabsahan teorinya dari segi metodologi penelitian ilmiah dan dari segi metodologi pemikiran filsafat. Penarikan sample yang terbatas pada orang yang mengidap gangguan psikologis dengan mengabaikan orang yang berpikiran waras serta agamawan yang taat tidaklah menunjukkan representasi tepat yang dapat 
dipertangungjawabkan secara ilmiah. Dan dari segi pemikiran filsafat yang menggunakan verifikasi yang ditopang dengan kegiatan observasi dan hukum kontradiksi tidak menunjukkan bahwa teori Freud mengenai agama memiliki landasan yang kuat.

\section{SEKS SEBAGAI DASAR MOTIVASI KEAGAMAAN}

Freud menyatakan bahwa motivasi beragama didasarkan pada dorongan seks. Freud memperkuat anggapannya dengan mengemukakan teori Oedipus Complex serta totemisme yang berkembang pada masyarakat primitif. Sebenarnya pandangan ini merupakan gagasan Freud untuk mengkritik sistem keagamaan yang berkembang pada masa hidupnya. Para pemuka agama pada saat itu mengharamkan dirinya untuk kawin karena akan merusak kesucian dirinya dan menghalanginya untuk berkonsentrasi dalam menekuni berbagai kegiatan keagamaan yang menjadi bidang pengabdiannya.

Konsep Oedipus Complex dan totemisme merupakan penggambaran dari hubungan anak-ibu dan bapak. Anak yang mencintai ibunya merasakan adanya hambatan besar dalam melawan kewibawaan dan kekuasaan mutlak Bapa yang menguasai ibu. Hubungan yang penuh dengan konflik yang kemudian direpres dan disublimasikan sebagai pemujaan kepada Bapa yang dianggap sebagai Tuhan yang maha kuasa.

Teori Freud yang mengandalkan seks sebagai dasar kegiatan keagamaan dianut beberapa sekte keagamaan. Kegiatan Children of God, suatu sekte keagamaan yang memberikan kebebasan kepada penganutnya untuk berhubungan seks secara bebas dengan siapa saja, merupakan penerapan teori Freud yang mendasarkan motivasi kegiatan keagamaan pada seks. Film "The Armour of God" yang dibintangi Jacki Chan merupakan pecerminan teori Freud yang diangkat ke atas layar perak. Film ini menggambarkan betapa pemuka dan pemeluk setia suatu aliran keagamaan secara rutin mendatangkan para pelacur ke tempatnya untuk memuaskan nafsunya. Nafsu seks diangapnya sebagai suatu kegiatan yang dapat menumbuhkan semangat pengabdiannya terhadap agama, walaupun kegiatan itu mrereka lakukan secara terselubung dan di luar kontrol pengawasan lingkungannya. Gejala semacam ini ditanggapi oleh Abdul Rahman Habnakah dengan memperingatkan kaum muslimin agar berhati-hati kepada gerakan Freemansory yang menggunakan teori Freud untuk merusak dan menghancurkan akidah agama. ${ }^{17}$.

Pandangan Freud yang menyatakan bahwa agama dimotivasi oleh dorongan libido seksual tidak terlepas dari pandangannya mengenai hakekat manusia. Walaupun struktur kepribadian manusia terdiri atas tiga 
aspek yakni Id, Ego, dan Superego, tetapi pemegang sumber energi adalah Id. Kedua aspek kepribadian lainnya merupakan derivat Id dan sangat bergantung kepada kemurahan Id untuk membagikan energinya. Kekuatan pendorong yang paling kuat dalam Id adalah libido seksual yang menggerakkan segenap aktivitas manusia termasuk perilaku beragama.

Pandangan Freud mengenai hakekat manusia ini sangat deterministik dan negatif. Perilaku manusia ditentukan oleh Id. Manusia dipandang sebagai korban permainan nafsu libido yang disalurkan dan dikuasai oleh Id dengan prinsip kenikmatan untuk memenuhi kebutuhan-nya serta menghindari rasa sakit. Pandangan ini menempatkan manusia sebagai pribadi yang terikat dan terbelengu oleh libido, tidak mampu keluar dari jeratan seks, sehingga kegiatan keagamaanpun pada dasarnya adalah seks. Manusia tidak memiliki kebebasan pribadi untuk menentukan sendiri nasib dan hidupnya. Kehidupan beragama bukan merupakan suatu pilihan, tetapi merupakan akibat dari pengalaman traumatis masa kanakkanak yang digambarkan dalam Ooedipus Complex dan totemisme. Kegiatan beragama merupakan sublimasi yang terjadi pada masa kanakkanak. Sublimasi merupakan alat pertahanan ego, tetapi juga sekaligus menunjukkan ketidakmampuan ego menghadapi Id secara langsung dan berhadap-hadapan.

Carl Gustave Jung salah seorang murid Freud menentang pendapat gurunya yang terlalu bertumpu kepada libido seksual. Jung berpendapat bahwa motivasi beragama berakar dan bersumber dari 'natuur religiosa' bukan dari dorongan seksual. Natur religiosa merupakan fungsi agama yang alamiah dan bawaan seiring dengan keberadaan manusia. Jung bahkan berpendapat bahwa kesehatan psikis dan stabilitas psikis bergantung pada peran agama dalam pembentukan 'individuasi.'18 Ini bertentangan dengan mereka yang berpandangan bahwa agama adalah suatu ilusi, suatu pelarian dari realitas atau kelemahan yang kekanak-kanakan.

Sejarah kemanusiaan membuktikan bahwa kegiatan keagamaan terus menerus tumbuh dalam setiap diri manusia baik sebagai individu maupun masyarakat. Para antropolog senantiasa menaruh perhatian terhadap perkembangan kehidupan beragama dalam masyarakat. Ilmuwan sosiologi bahkan mencoba merumuskan fungsi agama. Muncullah berbagai macam pandangan tentang fungsi agama bagi perkembangan suatu masyarakat. Nottingham, yang membahas perkembangan agama berdasarkan analisa fungsional, mengemukakan bahwa agama memiliki kemampuan untuk mengintegrasikan masyarakat, mengatasi masalah-masalah penyesuaian diri manusia serta mengatasi ketidakseimbangan dan perubahan sosial. ${ }^{19}$

Dengan demikian, hipotesis Freud yang mengemukakan bahwa akar agama adalah libido seksual menimbulkan tanda tanya. Kemampuan 
seksual orang yang berusia lanjut dapat dikatakan mulai menurun, tetapi mereka pada umumnya menunjukkan grafik yang menaik dalam kegiatan keagamaan. Hasil penelitian menunjukkan bahwa kehidupan keagamaan pada usia lanjut ternyata meningkat, pengakuan terhadap realitas kehidupan akhirat baru muncul sampai $100 \%$ setelah usia 90 tahun. William James menyatakan, kegiatan keagamaan yang sangat luar biasa tampaknya justru terdapat pada usia tua. ${ }^{20} \mathrm{Hal}$ ini menunjukkan bahwa faktor seks bukan merupakan faktor penentu satu-satunya kehidupan beragama.

\section{AGAMA ADALAH ILUSI DAN NEUROSIS}

Freud menyatakan bahwa agama adalah ilusi, neurosis dan menghalangi pemikiran kritis. ${ }^{22}$ Padahal tidak semua agama demikian. Agama, khususnya Islam, sangat menghargai kebebasan berpikir sepanjang berada dalam koridor pemikiran yang tidak menyesatkan. ${ }^{23}$ Pemikiran filsafat pun mempunyai rambu-rambu metode berpikir yang ketat. Pemikiran yang bebas dapat disimak dalam dialog antara Tuhan dengan Ibrahim a.s. yang mempertanyakan bagaimana cara menghidupkan orang mati. Allah tidak menghukum Nabi Ibrahim atas pertanyaan yang seakan-akan meragukan keagunga-Nya, Allah bahkan memperkuat keimanan Ibrahim dengan jalan menunjukkan kearifan keagunganNya. Empat ekor burung lumat tercencang kemudian diletakkan di atas bukit yang berbeda arah. Setelah mendapatkan panggilan, burung itu hidup dan terbang kembali mendatangi Ibrahim a.s. Peristiwa itu bukan ilusi dari seorang penderita neurosis. Peristiwa itu kongkrit, bukan angan-angan, bukan salah persepsi terhadap stimulus yang ada seperti yang biasa muncul dalam kehidupan pengidap neurosis.

Menggunakan kebebasan berpikir dalam koridor pencarian kebenaran tidaklah sama dengan illusi dari seorang pengidap neurosis. Itulah sebabnya, Maslow menyatakan bahwa neurosis, psikosis, hambatan pertumbuhan - semuanya itu, menurut pandangannya - merupakan penyakitpenyakit kognitif yang juga mencemari fungsi pengamatan, belajar, ingatan, perhatian serta pikiran. ${ }^{24}$ Manusia yang sakit mentalnya karena mengalami neurosis tanpa bantuan pencerahan agama tidak akan mampu mencari kebenaran. Itulah sebabnya agama memerintahkan memelihara akal dan melarang mengkonsumsi sesuatu yang dapat merusaknya, sehingga dengan demikian akal dapat menjalankan fungsinya dengan jalan berpikir secara jernih dan bebas disertai pilihan bertanggungjawab untuk mengatasi berbagai masalah kehidupan manusia. Pilihan yang disertai dengan tangung jawab merupakan salah satu kualitas insani. Glasser mengemukakan bahwa tanggung jawab adalah "the ability to fulfill one's 
needs, and to do so in a way that doesn't deprive others of the ability to fulfill their needs." 25 Orang yang sakit mental karena mengidap neurosis tidak akan mampu memikul responsilibity semacam ini. Bahkan dia akan menjadi beban bagi orang lain. Sebaliknya agama sangat mengedepankan perasaan bertanggung jawab kepada penganutnya

Orang yang sering berilusi dan terkena neurosis adalah orang yang menggunakan dan menyalahgunakan obat-obat psikotropika seperti shabu-shabu, ganja, heroin dan semacamnya. Agama melarang keras penggunaan segala macam makanan, minuman, dan perbuatan yang dapat merusak akal pikiran manusia. Bahayanya bisa berakibat fatal karena dapat merusak jaringan otak manusia sehingga kehidupan pemakainya hanya akan dipenuhi dengan ilusi. Oleh karena itu, tidak mungkin orang yang beragama mengidap ilusi dan neurosis karena hal ini berarti dia sakit dan tidak dapat menjalankan fungsi pengabdiannya kepada Ilahi yang memerlukan kesadaran penuh. Hasil interogasi polisi terhadap pemakai obat-obat psikotropika pada umumnya adalah tergolong orang yang kurang memiliki keyakinan beragama yang kuat. Kasus Ayodhia Prasad Chaubey dan Selow Prasert yang dieksekusi pada tahun 2004 (lihat Fajar, 9 Pebruari 2006) memberi bukti konkret bahwa bukan agama yang menyebabkan illusi, tetapi agama yang mendidik manusia untuk tidak berilusi. ${ }^{26}$ Keduanya menjadi orang yang bertobat dan menjadi penganut agama yang taat setelah pengadilan memutuskan menjatuhkan hubuman mati kepada keduanya.

Kesediaan dan kesadaran untuk bertobat, ketenangan, ketegaran, dan kepasrahan menghadapi suatu masalah rumit bukan pertanda suatu ilusi. Keadaan kejiwaan ini menunjukkan pula bahwa agama bukan sia-sia dan tindakan infantilis. Akan tetapi, agama merupakan kekuatan penyembuh yang sangat besar bagi manusia yang mengalami kegoncangan emosi yang luar biasa.

\section{AGAMA SEBAGAI SUATU KONFLIK}

Pertumbuhan agama dapat saja dihubungkan dengan masa kanakkanak, tetapi bukan dalam situasi konflik antara orangtua-anak. Kehidupan beragama yang sehat adalah keyakinan beragama yang terbina sejak kecil yang dibangun berdasarkan cinta kasih dan kebersamaan yang menumbuhkan saling kepercayaan. Rumah tangga yang penuh dengan konflik tidak akan dapat mengantar anak menjadi seorang penganut agama yang sehat, dan taat menjalankan agama. Bukti-bukti menunjukkan bahwa remaja yang terlibat dalam narkotika, dan obat-obat terlarang berasal dari rumah tangga yang diselimuti dengan konflik. 
Erikson, seorang psikoanalis yang menjadi pengikut Freud, menekankan hubungan yang akrab antara orangtua-anak. Erikson berkeyakinan jalinan hubungan akrab antara orangtua-anak dapat menumbuhkan trust (kepercayaan). Konflik yang mengakibatkan ketidaknyamanan hanya menumbuhkan ketidakpercayaan. ${ }^{27}$ Bekal kemampuan untuk memiliki kepercayaan merupakan dasar terpokok dalam kehidupan beragama. Bekal kepercayaan yang tumbuh dalam pribadi anak yang dapat ditransfer menjadi keyakinan beragama melalui suatu proses pendidikan yang didasarkan pada pandangan bahwa anak memiliki naluri beragama. Dengan demikian Erikson mementahkan asumsi dasar yang dikemukakan Freud bahwa konflik yang mendasari agama.

Argumen Freud mengenai oedipus complex dan totemisme hanyalah merupakan upaya Freud untuk menjustifikasi dan membenarkan teorinya. Kehidupan orang-orang primitif yang mendasarkan kehidupan beragamanya kepada keyakinan totemisme tidak dapat dijadikan sebagai suatu landasan bahwa agama merupakan desakan libidinal yang tumbuh sejak masa kanak-kanak. Alasan tersebut terlalu menyederhanakan logika dalam menggeneralisasi suatu gejala perilaku beragama dengan satu penarikan konklusi yang keliru.

\section{PENDIDIKAN AGAMA: KATARSIS VERSUS FITRAH}

Salah satu uraian Freud yang menarik perhatian adalah Super Ego. Dia menjelaskan bahwa Super Ego merupakan aspek kepribadian yang memuat unsur-unsur moral, nilai-nilai, dan adat istiadat. Sesuatu yang berhubungan dengan moral dan nilai-nilai, walaupun tidak semuanya, biasanya dikaitkan dengan agama. Internalisasi nilai-nilai menjadikan Super Ego berkembang menjadi pengawas atau hakim bagi individu sendiri yang bertindak menghadapi dorongan libidinal, mengarahkan dan mengatur hubungannya dengan Ego atau diri yang disadari Super Ego menjadi kritikus tertinggi bagi akhlaq. Super Ego menyebabkan Ego merasa bersalah (guilty feeling), apabila terjadi sesuatu yang tidak disenanginya. Freud menyimpulkan fungsinya sebagai hati nurani yang tidak disadari (The Unconscious Conscience). Brown bahkan menyebutnya sebagai Kritikus Tertinggi yang tidak disadari bagi mental manusia (The Unconscious Higher Critic of the Mind). ${ }^{28}$ Perhatian utama Super Ego adalah memutuskan apakah seseuatu itu benar atau salah. Dengan demikian, ia dapat bertindak sesuai dengan norma-norma moral yang diakui oleh wakil-wakil masyarakat. ${ }^{29}$ Super Ego berperan sebagai penjaga moral. ${ }^{30}$

Super ego terbentuk melalui proses penyerapan dan pelemparan (introjection and projection). ${ }^{31}$ Individu belajar mengembangkan dirinya 
dengan proses penyerapan dan projection untuk mereduksikan keteganganketengang yang semakin meningkat seiring dengan perkembangannya. Individu menyerap nilai-nilai dari individu lain yang signifikan. Kesankesan yang tersimpan kuat dalam memori kemudian diproyeksikan keluar dalam upaya merealisasikan dan menyalurkan keinginan-keinginan Id yang disesuaikan dengan prinsip realitas ego. ${ }^{32}$

Identifikasi dan displacement merupakan cara yang digunakan individu dalam kerangka penyerapan nilai. Identifikasi merupakan metode belajar yang digunakan individu untuk mengambil alih ciri-ciri orang lain dan menjadikannya bagian yang tak terpisahkan dari kepribadiannya sendiri. Orang belajar mereduksikan tegangan dengan cara bertingkah laku seperti tingkah laku orang lain. Biasanya orang memilih dan mengambil hal-hal yang dirasakannya akan menolong untuk mencapai tujuan yang diinginkan. Ujian terakhir adalah apakah identifikasi itu membantu mereduksikan tengangan, jika ya maka kualitas itu diambil alih, kalau tidak maka akan dibuang. ${ }^{33}$

Individu menggunakan proses displacement apabila obyek asli yang dipilih tidak dapat dicapai karena adanya rintangan baik dari luar maupun dari dalam (anti kateksis), kecuali jika terjadi suatu represi. Apabila kateksis yang baru itu juga terhalang, maka akan terjadi pemindahan. Demikian seterusnya sampai ditemukan obyek yang mampu mengurangi tegangan yang tak tersalurkan. ${ }^{34}$

Walaupun kepribadian memiliki aspek yang bernama Superego, tetapi Freud berpandangan bahwa sumber motivasi beragama adalah dorongan libido seksual dalam kerangka Oedipus Complex. Individu memberikan gambaran tuhan terhadap ayah yang tidak dapat dilawannya dalam menyalurkan rasa cintanya kepada ibu. Perlawanan terhadap ayah menimbulkan ketegangan dan kecemasan. Dengan degitu, individu lalu memindahkan obyek ketegangan dan kecemasan kepada mentaati ayah yang memiliki otoritas sekaligus mengidentifikasi sifat-sifat ayah. Proses ini berlangsung melalui mekanisme pertahanan diri yang dikenal dengan istilah sublimasi. Namun, sublimasi tidak memberikan kepuasan yang sempurna, selalu terdapat sisa tegangan. Tegangan itu bisa muncul dalam bentuk sikap neurosis atau kegelisahan. ${ }^{35}$

Agama sebagai hasil sublimasi menjadikan manusia mengalami neurosis dan kegelisahan. Agama tidak pernah menjadikan individu keluar dari ketegangan dan kecemasan. Pengaruh konflik dan dorongan seks libidinal oedipus yang harus terpuaskan dari Id yang memiliki sumber energi terus menerus mempengaruhi individu. Bahkan, biasanya agama yang berada dalam Super Ego dijadikan tidak berdaya oleh Id. Super Ego 
hanya berdaya bila Id memberinya energi. Sehingga yang tersisa hanya perasaan bersalah (guilty feeling), bila telah melakukan suatu pelanggaran. Dengan begitu, agama tidak pernah menumbuhkan perkembangan pribadi. Sebaliknya, perasaan bersalah pun merupakan salah satu sumber yang menghambat perkembangan pribadi. Itulah sebabnya, agama tidak diperlukan, karena itu upaya pendidikan agama dipandang hanya perbuatan sia-sia dan juga merugikan pertumbuhan kepribadian manusia. ${ }^{36}$ Freud berkeyakinan bahwa indoktrinasi agama menimbulkan represi yang menyebabkan ketakutan dan menimbulkan keengganan untuk melatih berpikir kritis. ${ }^{37}$ Freud berkeyakinan bahwa "a mature person would abandon religion. And that person needed to face the world on his or her own, rather than relying on a god who was based on neurotic proyection of the father from the childhood." 38

Freud tidak memasukkan agama dalam proses pendidikan. Agama harus dijauhkan dari kehidupan manusia karena akan merusak perkembangan kepribadian individu. Mekanisme yang dipergunakan oleh Freud untuk menolak agama adalah katarsis. Katarsis adalah metode melepaskan konflik dan gangguan illusi dengan melampiaskan keluar apa yang terkandung dalam hati. Metode ini secara sistematis digunakan untuk membawa faktor-faktor yang tidak disadari (Freud menganggap bahwa agama merupakan proses tak sadar) keluar ke alam kesadaran untuk menumbuhkan pemahaman intelektual dan mendorong terjadinya perubahan kepribadian. ${ }^{39}$ Perubahan yang dimaksud, salah satunya, adalah kesadaran melepaskan keyakinan beragama yang menjadi sumber neurotik bagi manusia. Pernyataan-pernyataan Freud yang negatif terhadap agama merupakan bentuk pengungkapan katarsis.

Pandangan berbeda dikemukakan oleh para ahli yang lain. Mereka menganggap pendidikan agama sebagai hal yang esensial bagi eksistensi manusia. Victor Frankl, umpamanya, mengemukakan bahwa "man lives in three dimensions: the somatic, the mental and the spiritual. The spiritual dimension cannot be ignored, for it is what makes us human." 40 Dimensi yang dimiliki manusia perlu dikembangkan seoptimal mungkin dan dimensi yang paling menentukan eksistensi manusia adalah dimensi spiritual. Pengembangan dimensi kepribadian manusia dimaksudkan agar individu dapat mengecap kebermaknaan hidup. Frankl mengemukakan bahwa "the supra meaning can be grasped only by faith and not by intellectual means...Trust in God precedes people's ability to have faith in life's ultimate meaning." $41 \mathrm{Di}$ sinilah pentingnya pendidikan agama sebagai pembangkit kehidupan spiritual manusia.

Ali Shariati membahas eksistensi manusia dengan mengemukakan unsur Ruh sebagai the spirit of God. Beliau menjelaskan kedudukan tanah 
dan ruh. Kedua unsur itu seakan-akan merupakan kutub-kutub yang berlawanan. Tanah adalah unsur yang bersifat fisik, statis, mati dan letaknya rendah di bawah, sedangkan ruh letaknya metafisis (ghaib), dinamis, menghidupkan, dan "luhur" di atas. ${ }^{42}$ Ruh adalah daya hidup yang memberikan kekuatan sehingga pikiran, perasaan, kemauan, begitu juga alat-alat indera dan kekuatan anggota tubuh dapat berfungsi. Oleh karena itu, keseluruhan potensi manusia perlu dikembangkan secara selaras untuk menjadi abdi Ilahi. Agama mendidik totalitas kepribadian individu.

Mohammed Yasien mengecam teori Freud mengenai agama sebagai sangat spekulatif, deterministik, mekanistik, sekular, dan menolak eksistensi esensi spiritual manusia. Dia mengemukakan bahwa Freud mengabaikan unsur spiritual dalam diri manusia yang bersumber dari fitrah. Mohammad menjelaskan bahwa fitrah merupakan kekuatan pendorong utama bawaan atau dorongan untuk mengimani, menyembah, dan mematuhi Allah swt. Fitrah adalah kemampuan dasar bawaan manusia yang setiap saat dapat berkembang. Fitrah berisi bibit unggul perkembangan agama bagi setiap insan. Dia dapat tumbuh dalam berbagai lingkungan lahan yang tersedia. Lahan yang subur, cocok dan sesuai dengan hakekat dengan bibit fitrah, akan menjadikan insan terbuka mata batinnya menghayati Tuhan dengan segala kebenaranNya. ${ }^{43}$ Abdul Mudjib menyebut potensi beragama ini sebagai fithrah ilahiyaah atau fithrah rabbaniyyah nuraniyah yang substansi naturnya suci dan halus. ${ }^{44}$

Fitrah sejalan dengan blue print peniupan ruh. Ruh adalah sesuatu yang melekat dalam kehidupan manusia. Sifatnya yang suci dan halus mendorongnya untuk senantiasa berhubungan akrab dengan sumber kekuasaan mutlak yaitu Yang Maha Muasa. Agama mengakui keberadaan nafsu yang memiliki kekuatan pendorong untuk melakukan sesuatu. Akan tetapi, agama tidak akan membiarkan nafsu bertindak secara liar. Agama akan mendidik nafsu agar terkendali dan tersalur untuk menjaga kesucian martabat manusia. Dalam agama Islam, terutama mereka yang terjun dalam kegiatan sufi, senantiasa berusaha mendidik nafsu dengan jalan tazkiyah al-nafs sehingga ruh yang suci tetap terpelihara dan bersinar dalam kepribadian insani. Nafsu ammarah menjadi terkendali dan terarah mendapatkan nur dari nafsu muthmainnah yang senantiasa memberikan ketenangan dan kebahagiaan hidup karena senantiasa akrab dengan Tuhan pencipta manusia.

Ruh sebagai the spirit of God adalah kekuatan pamungkas dalam diri manusia dalam menghadapi dan mengendalikan berbagai desakan naluri rendah. Kekuatan pamungkas ini tumbuh berkembang melalui pendidikan 
agama. Pendidikan agama yang akan mengantar manusia mengenal Tuhannya sesuai dengan the spirit of God tersebut. Mengenal Tuhan merupakan pilar utama agama. Pengenalan dan pengabdian yang tulus terhadap Tuhan yang akan menuntun manusia untuk menggunakan segala potensi baik jasmani maupun ruhani ke arah pembentukan kepribadian yang utuh dan menyelamatkan dirinya dan sesamanya, bukan saja di dunia tetapi juga di akhirat. ${ }^{45}$ Keyakinan beragama berdasarkan spirit of God memiliki dimensi kemanusiaan yang halus dan menumbuhkan kehidupan bersama. Hal ini yang tidak pernah diungkap oleh Freud dalam berbagai ulasan ilmiahnya.

\section{PENUTUP}

Uraian yang berisi kritik terhadap pandangan Freud mengenai agama dapat disimpulkan sebagai berikut:

1. Cacat metodologis menjadi keberatan paling utama terhadap teori Freud mengenai agama. Hal ini ditujukan kepada penarikan sample yang terbatas, sistem verifikasi dengan penggunaan observasi dan hukum kontradiksi serta daya prediksi teori yang kurang mamadai. Cacat metodologis ini menjadi celah keberatan para ilmuwan terhadap teori Freud mengenai agama.

2. Seks bukan satu-satunya penentu kepribadian manusia. Manusia memiliki sejumlah kualitas insani seperti fitrah, kebebasan serta pertanggungjawaban yang memberikan kepadanya kesempatan untuk memilih dan berbuat menurut keyakinan beragama. Manusia bukan korban dari dorongan libido seksual untuk menjalankan aktivitas keberagamaannya. Libido seksual tidak dapat dijadikan sebagai sumber motivasi beragama karena sifatnya yang liar, tidak terkendali dan hanya mengejar kenikmatan material dan mengabaikan hal-hal yang bersifat spiritual sebagai salah satu potensi dasar manusia.

3. Penganut agama yang taat adalah manusia yang memiliki kesehatan mental, yang jauh lebih baik dari orang yang terkena ilusi dan mengidap neurosis. Ilusi dan neurosis menyebabkan manusia lebih banyak berkhayal buta untuk tidak mengabdikan dirinya bagi kemajuan peradaban dan membangun kemanusiaan. Panggung sejarah mempunyai bukti otentik peran agama dalam membangun kemanusiaan dan peradaban yang tidak dicapai oleh orang yang sakit seperti mengidap illusi dan neurosis.

4. Konflik ayah, ibu, dan anak dalam rumah tangga tidak akan pernah menguntungkan perkembangan kehidupan beragama seorang anak. Apalagi kalau konflik itu direpres, karena konflik yang demikian akan 
selalu mengganggu kehidupan emosi seorang individu. Agama dapat berkembang dengan baik dalam suasana rumah tangga yang tenang disertai rasa kasih sayang yang muncul dari pasangan suami isteri. Hubungan kekerabatan antar keluarga akan menimbulkan cikal bakal kepercayaan yang menjadi pondasi kehidupan beragama.

5. Pendidikan agama merupakan wadah untuk mengembangkan fitrah manusia yang selaras dengan keberadaan ruh yang suci. Fitrah merupakan potensi dasar manusia untuk menerima upaya pendidikan agama. Pendidikan agama akan memberikan kemampuan untuk memanfaatkan seluruh potensi individu untuk mengenal Tuhan sekaligus membangun kemanusiaan. Sangat berbanding terbalik dengan pandangan Freud yang menyatakan bahwa agama tidak diperlukan dalam kehidupan karena agama adalah ilusi yang tidak bermanfaat bagi kehidupan manusia.

\section{CATATAN AKHIR:}

1. Abdul Rahman Barakatu, "Pandangan Sigmund Freud Terhadap Agama", Lentera Akademika, Edisi IV Tahun 2002, h. 1-21.

2. John Naisbitt \& Patricia Aburdene, The New Direction for the 1900's: Megatrend 2000, diterjemahkan oleh Budiyanto dengan judul: Sepuluh Arah Baru untuk Tahun 1900-an: Megatrends 2000, Jakarta: Binarupa Aksara, 1990, h. 254-280.

3. Lihat Craig S. Cashwell \& J. Scout Young, Integrating Spirituality and Religion into Counseling: An Introduction, In Craig S. Cashwell \& J. Scout Young (Eds), Integrating Spirituality and Religion into Counseling: A Guide to Competent Practice. Alexanndria, VA: American Counseling Association. h. 1-10. Quoted from Princeton Religion Research Center, American Remain Very Religious, But not Necessarily in Conventional Ways, Emerging Trends (2000), 22 (1), 2-3.

4. Gerald Corey, Theory and Practice of Counseling and Psychotherapy (3rd Ed.), Monterey, California: Brooks/Cole Publishing Company, 1984, h. 81.

5. Lihat H. M. Rasjidi, Filsafat Agama, Djakarta: N.V. Pemandangan, 1965, h. 129.

6. Djamaluddin Ancok \& Fuat Nashori Suroso, Psikologi Islami: Solusi Islam atas Problem-problem Psikologi, cet. ketiga, Yogyakarta: Pustaka Pelajar, h. 63. lihat ulasan Hanna Djumhana Bastaman, Integrasi Psikologi dengan Islam: Menuju Psikologi Islami, cet. pertama, Yogyakarta: Pustaka Pelajar, 1995, h. 57.

7. Lihat Alfons Taryadi, Epistemologi Pemecahan Masalah: Menurut Karl R. Popper, Jakarta: Gramedia Pustaka Utama, 1991, h. 42.

8. Louis O. Kattsoff, Elements of Philosophy, diterjemahkan oleh Soejono Soemargono dengan judul: Pengantar Filsafat, Yogyakarta: Tiara Wacana, 1992, h. 33.

9. Calvin S. Hall \& Gardner Lindzey, Theories of personality, diterjemahkan oleh Yustinus dengan judul: Psikologi Kepribadian I: Teori-teori Psikodinamik (Klinis), Yogyakarta: Kanisius, 1993, h. 111.

10. Ratna Willis Dahar, Teori-teori Belajar, Jakarta: Erlangga, 1989, h. 3. 
11. Dedi Supriadi, Kreativitas, Kebudayaan, dan Perkembangan Iptek. Bandung: Alfabeta, 1994, h. 71.

12. Bishop Religious Values as Cross-Cultural Issues in Counseling, Counseling and Values, 1992, h. 179-193.

13. Richard E. Creel, Religion and Doubt: Toward a Faith of Your Own (2nd ed.), Englewood Cliffs, New Jersey: Prentice Hall, 1991, h. 126.

14. Louis O. Kattsoff, Elements of Philosophy, diterjemahkan oleh Soejono Soemargono dengan judul: Pengantar Filsafat, h. 453.

15. Roger Garaudy, Biographie Du XX Siecle le Testament Philosophique, diterjemahkan oleh Rasjidi dengan judul: Mencari Agama pada Abad XX: Wasiat Filsafat Roger Garaudy, Jakarta: Bulan Bintang, 1986, h. x.

16. Cassirer, E., An Essay on Man, diterjemahkan oleh Alois A. Nugroho dengan judul: Manusia dan Kebudayaan: Sebuah Esei tentang Manusia, Jakarta: Gramedia, 1990, h. 109.

17. Abdulah Nashih Ulwan, Tarbiyyah al-Aulad fi al-Islam, diterjemahkan oleh Kamalie S. dengan judul: Pedoman Pendidikan Anak dalam Islam, jilid 2, Semarang: Al-Syifa, 1981, h. 206.

18. John W. M. Verhaar, Identitas Manusia menurut Psikologi dan Psikiatri Abad ke 20, Yogyakarta: Kanisius. 1993. h. 36. Bandingkan dengan uraian Fordham F., Pengantar Psikologi C. G. Jung: Teori-teori dan Teknik Psikologi Kedokteran, diterjemahkan oleh Istiwidayanti, Jakarta: Bhatara Karya Aksara, 1988, h. 54.

19. Baca Elizabeth K. Nottingham, Religion and Society, diterjemahkan oleh Naharong Abdul Azis dengan judul: Agama dan Masyarakat: Suatu Pengantar Sosiologi Agama, Jakarta: RajaGrafindo Prasada, 1994, h. 31-48.

20. Robert H. Thouless, An Introduction to the Psychology of Religion, diterjemahkan oleh Machnun Husein dengan judul: Pengantar Psikologi Agama, cet. pertama, Jakarta: Rajawali, 1992, h. 108. Lihat juga Jalaluddin, Psikologi Agama, cet. kedua, Jakarta: RajaGrafindo Persada, 1997, h. 98.

21. Frank G. Goble, The Third Force, The Psychology of Abraham Maslow, diterjemahkan oleh A. Supratiknya dengan judul: Mazhab Ketiga, Psikologi Humanistik Abraham Maslow, cet. keempat, Yogyakarta: Kanisius, 1994, h. 92.

22. Lihat Marsha Wiggins-Frame, "Spirituality and Religion: Similarities and Differences", In Craig S. Cashwell \& J. Scout Young (Eds), Integrating Spirituality and Religion into Counseling: A Guide to Competent Practice. Alexandria, VA: American Counseling Association, h. 11-30.

23. Aisyah Abdurrahman, Maqal fi al-Islam; Dirasah Qur'aniyyah, diterjemahkan oleh M. Adib al-Arief dengan judul: Manusia Sensitivitas; Hermeneutika AlQur'an. Yogyakarta: LKPSM, 1997, h. 75-145. Lihat juga M. Quraisy Syihab, Membumikan Al-Quran: Fungsi dan Peran Wahyu dalam Kehidupan Masyarakat. Bandung: Mizan, 1992, h. 75-82. Demikian juga ulasan Ahmad Syafii Maarif, Membumikan Islam, Yogyakarta: Pustaka Pelajar, 1995, h. 14-19.

24. Frank G. Goble, The Third Force, The Psychology of Abraham Maslow, diterjemahkan oleh A. Supratiknya dengan judul: Mazhab Ketiga, Psikologi Humanistik Abraham Maslow. h. 126.

25. Bruce Joice \& Marsha Weil, Models of Teaching (2nd ed.), Englewood Cliffs, New Yersey: Prentice-Hall International, 1980, h. 209. 
26. "Empat Juta Penduduk RI Pecandu Narkoba" [berita] Fajar, Nomor 125 Tahun ke 24 Kamis, 09 Februari 2006, h. 1.

27. Stephen N. Elliot, Thomas R. Kratochwill, Joan Littlefield Cook \& John E. Travers, Educational Psychology: Effective Teaching Effective Learning (3rd ed.), International Edition, Singapore: McGraw-Hil Book, 2000, h. 72-73.

28. Abdul Aziz Al Quussy, Ususu al-Shihhah al-Nafsiyyah, diterjemahkan oleh Zakiyah Daradjat dengan judul: Pokok Pokok Kesehatan Jiwa/Mental, Jakarta: Bulan Bintang, 1974, h. 154.

29. Calvin S. Hall \& Gardner Lindzey, Theories of Personality, diterjemahkan oleh Yustinus dengan judul: Psikologi Kepribadian I: Teori-teori Psikodinamik (Klinis), Yogyakarta: Kanisius 1993, h. 67.

30. Robert W. Crapps, An Introduction to Psychology of Religion, diterjemahkan oleh A. M. Hardjana dengan judul: Dialog Psikologi dan Agama, Yogyakarta: Kanisius, 1993.

31. Abdul Aziz Al Quussy, Ususu al Shihhah al Nafsiyyah, diterjemahkan oleh Zakiyah Daradjat dengan judul: Pokok-pokok Kesehatan Jiwa/Mental, h. 154. Lihat juga Peter Connolly, Approaches to the Study of Religion, diterjemahkan oleh Imam Khoiri dengan judul: Aneka Pendekatan studi Agama, Yogyakarta: LKIS, 2002, h. 205-206.

32. Sumadi Suryabrata, Psikologi Kepribadian, Jakarta: Rajawali,1985, h. 169.

33. Abdul Aziz Al Quussy, Ususu al-Shihhah al-Nafsiyyah, diterjemahkan oleh Zakiyah Daradjat dengan judul: Pokok-pokok Kesehatan Jiwa/Mental, Jakarta: Bulan Bintang, 1974, h. 153. Lihat juga Calvin S. Hall \& Gardner Lindzey, Theories of Personality, diterjemahkan oleh Yustinus dengan judul: Psikologi Kepribadian I: Teori-teori Psikodinamik (Klinis), h. 83-84.

34. Calvin S. Hall \& Gardner Lindzey, Theories of Personality, diterjemahkan oleh Yustinus dengan judul: "Psikologi Kepribadian I: Teori-teori Psikodinamik (Klinis)," Yogyakarta: Kanisius 1993, h. 84.

35. Calvin S. Hall \& Gardner Lindzey (1993), Theories of Personality, diterjemahkan oleh Yustinus dengan judul: Psikologi Kepribadian I: Teori-teori Psikodinamik (Klinis), h. 86.

36. Robert W. Crapps, An introduction to psychology of religion, diterjemahkan oleh A. M. Hardjana dengan judul: Dialog Psikologi dan Agama, h. 72.

37. Marsha Wiggins-Frame, Spirituality and Religion: Similarities and Differences, In Craig S. Cashwell \& J. Scout Young (Eds), Integrating Spirituality and Religion into Counseling: A Guide to Competent Practice, h. 11-30.

38. Gerl Miller, "Religious/Spiritual Life Span Development." In Craig S. Cashwell \& J. Scout Young (Eds), Integrating Spirituality and Religion into Counseling: A Guide to Competent Practice, h. 105-122.

39. Robert W. Crapps, An Introduction to Psychology of Religion, diterjemahkan oleh A. M. Hardjana dengan judul: Dialog Psikologi dan Agama, h. 59.

40. Hanna Djumhana Bastaman, Integrasi Psikologi dengan Islam: Menuju Psikologi Islami, cet. pertama, Yogyakarta: Pustaka Pelajar, 1995, h. 64.

41, Richard Nelson Jones, Counseling and Personality: Theory and Practice, St. Leonard, NSW Australia: Allen \& Unwin, 1995, h. 169.

42. Hanna Djumhana Bastaman, Integrasi Psikologi dengan Islam: Menuju Psikologi Islami, h. 64. 
43. Yasien Mohamed, Fitra: The Islamic Concept of Human Nature, diterjemahkan oleh Masyhur Abadi dengan judul: Insan yang Suci: Konsep Fithrah dalam Islam. Bandung: Mizan, 1997, h. 167.

44. Abdul Mujib, Kepribadian dalam Psikologi Islam, Jakarta: RajaGrafindo Persada, 2006, h. 88

45. Lihat Nurcholish Madjid, Islam Doktrin dan Peradaban: Sebuah Telaah Kritis tentang Masalah Keimanan, Kemanusiaan, dan Kemoderenan, Jakarta: Paramadina, 1992, h. 93-111. Lihat juga Murtadha Muthahhari, Hikmat-ha va Andaruz-ha, diterjemahkan oleh Ahmad Subandi dengan judul: Jejak-jejak Ruhani, Bandung: Pustaka Hidaya, 1996, h. 7-17.

\section{DAFTAR PUSTAKA:}

Abdurrahman, Aisyah, Maqal fi al-Islam; Dirasah Qur'aniyyah, diterjemahkan oleh M. Adib al-Arief dengan judul: Manusia Sensitivitas; Hermeneutika Al-Qur'an. Yogyakarta: LKPSM, 1997.

Ancok, Djamaluddin \& Fuat Nashori Suroso, Psikologi Islami: Solusi Islam atas Problem-problem Psikologi, cet. ketiga, Yogyakarta: Pustaka Pelajar.

Barakatu, Abdul Rahman, "Pandangan Sigmund Freud Terhadap Agama", Lentera Akademika, Edisi IV Tahun 2002.

Bastaman, Hanna Djumhana, Integrasi Psikologi dengan Islam: Menuju Psikologi Islami, cet. pertama, Yogyakarta: Pustaka Pelajar, 1995.

Bishop Religious Values as Cross-Cultural Issues in Counseling, Counseling and Values, 1992.

Cashwell, Craig S. \& J. Scout Young, Integrating Spirituality and Religion into Counseling: An Introduction, In Craig S. Cashwell \& J. Scout Young (Eds), Integrating Spirituality and Religion into Counseling: A Guide to Competent Practice. Alexanndria, VA: American Counseling Association. Quoted from Princeton Religion Research Center, American Remain Very Religious, But not Necessarily in Conventional Ways, Emerging Trends (2000).

Cassirer, E., An Essay on Man, diterjemahkan oleh Alois A. Nugroho dengan judul: Manusia dan Kebudayaan: Sebuah Esei tentang Manusia, Jakarta: Gramedia, 1990.

Connolly, Peter, Approaches to the Study of Religion, diterjemahkan oleh Imam Khoiri dengan judul: Aneka Pendekatan studi Agama, Yogyakarta: LKIS, 2002.

Corey, Gerald, Theory and Practice of Counseling and Psychotherapy (3rd Ed.), Monterey, California: Brooks/Cole Publishing Company, 1984.

Crapps, Robert W., An Introduction to Psychology of Religion, diterjemahkan oleh A. M. Hardjana dengan judul: Dialog Psikologi dan Agama, Yogyakarta: Kanisius, 1993.

Creel, Richard E., Religion and Doubt: Toward a Faith of Your Own (2nd ed.), Englewood Cliffs, New Jersey: Prentice Hall, 1991.

Dahar, Ratna Willis, Teori-teori Belajar, Jakarta: Erlangga, 1989.

Elliot, Stephen N., Thomas R. Kratochwill, Joan Littlefield Cook \& John E. Travers, Educational Psychology: Effective Teaching Effective Learning (3rd ed.), International Edition, Singapore: McGraw-Hil Book, 2000. 
"Empat Juta Penduduk RI Pecandu Narkoba" [berita] Fajar, Nomor 125 Tahun ke 24 Kamis, 09 Februari 2006.

Garaudy, Roger, Biographie Du XX Siecle le Testament Philosophique, diterjemahkan oleh Rasjidi dengan judul: Mencari Agama pada Abad XX: Wasiat Filsafat Roger Garaudy, Jakarta: Bulan Bintang.

Goble, Frank G., The Third Force, The Psychology of Abraham Maslow, diterjemahkan oleh A. Supratiknya dengan judul: Mazhab Ketiga, Psikologi Humanistik Abraham Maslow, cet. keempat, Yogyakarta: Kanisius, 1994.

Hall, Calvin S. \& Gardner Lindzey (1993), Theories of Personality, diterjemahkan oleh Yustinus dengan judul: Psikologi Kepribadian I: Teori-teori Psikodinamik (Klinis), h. 86.

Hall, Calvin S. \& Gardner Lindzey, Theories of personality, diterjemahkan oleh Yustinus dengan judul: Psikologi Kepribadian I: Teori-teori Psikodinamik (Klinis), Yogyakarta: Kanisius, 1993, h. 111.

Hall, Calvin S. \& Gardner Lindzey, Theories of Personality, diterjemahkan oleh Yustinus dengan judul: Psikologi Kepribadian I: Teori-teori Psikodinamik (Klinis), Yogyakarta: Kanisius 1993.

Jalaluddin, Psikologi Agama, cet. kedua, Jakarta: RajaGrafindo Persada, 1997.

Joice, Bruce \& Marsha Weil, Models of Teaching (2nd Ed.), Englewood Cliffs, New Yersey: Prentice-Hall International, 1980.

Jones, Richard Nelson, Counseling and Personality: Theory and Practice, St. Leonard, NSW Australia: Allen \& Unwin, 1995.

Kattsoff, Louis O., Elements of Philosophy, diterjemahkan oleh Soejono Soemargono dengan judul: Pengantar Filsafat, Yogyakarta: Tiara Wacana, 1992.

Maarif, Ahmad Syafii, Membumikan Islam, Yogyakarta: Pustaka Pelajar, 1995.

Madjid, Nurcholish, Islam Doktrin dan Peradaban: Sebuah Telaah Kritis tentang Masalah Keimanan, Kemanusiaan, dan Kemoderenan, Jakarta: Paramadina, 1992.

Miller, Gerl, "Religious/Spiritual Life Span Development." In Craig S. Cashwell \& J. Scout Young (Eds), Integrating Spirituality and Religion into Counseling: A Guide to Competent Practice.

Mohamed, Yasien, Fitra: The Islamic Concept of Human Nature, diterjemahkan oleh Masyhur Abadi dengan judul: Insan yang Suci: Konsep Fithrah dalam Islam. Bandung: Mizan, 1997.

Mujib, Abdul, Kepribadian dalam Psikologi Islam, Jakarta: RajaGrafindo Persada, 2006.

Muthahhari, Murtadha, Hikmat-ha va Andaruz-ha, diterjemahkan oleh Ahmad Subandi dengan judul: Jejak-jejak Ruhani, Bandung: Pustaka Hidaya, 1996.

Naisbitt, John \& Patricia Aburdene, The New Direction for the 1900's: Megatrend 2000, diterjemahkan oleh Budiyanto dengan judul: Sepuluh Arah Baru untuk Tahun 1900-an: Megatrends 2000, Jakarta: Binarupa Aksara, 1990.

Nottingham, Baca Elizabeth K., Religion and Society, diterjemahkan oleh Naharong Abdul Azis dengan judul: Agama dan Masyarakat: Suatu Pengantar Sosiologi Agama, Jakarta: RajaGrafindo Prasada, 1994.

Al-Quussy Abdul Aziz, Ususu al-Shihhah al-Nafsiyyah, diterjemahkan oleh Zakiyah Daradjat dengan judul: Pokok Pokok Kesehatan Jiwa/Mental, Jakarta: Bulan Bintang, 1974.

Rasjidi, H. M., Filsafat Agama, Djakarta: N.V. Pemandangan, 1965. 
Supriadi, Dedi, Kreativitas, Kebudayaan, dan Perkembangan Iptek. Bandung: Alfabeta, 1994.

Suryabrata, Sumadi, Psikologi Kepribadian, Jakarta: Rajawali,1985.

Syihab, M. Quraisy, Membumikan Al-Quran: Fungsi dan Peran Wahyu dalam Kehidupan Masyarakat. Bandung: Mizan, 1992.

Taryadi, Alfons, Epistemologi Pemecahan Masalah: Menurut Karl R. Popper, Jakarta: Gramedia Pustaka Utama, 1991.

Thouless, Robert H., An Introduction to the Psychology of Religion, diterjemahkan oleh Machnun Husein dengan judul: Pengantar Psikologi Agama, cet. pertama, Jakarta: Rajawali, 1992.

Ulwan, Abdulah Nashih, Tarbiyyah al-Aulad fi al-Islam, diterjemahkan oleh Kamalie S. dengan judul: Pedoman Pendidikan Anak dalam Islam, jilid 2, Semarang: AlSyifa, 1981.

Verhaar, John W. M., Identitas Manusia menurut Psikologi dan Psikiatri Abad ke 20, Yogyakarta: Kanisius. 1993.

Fordham F., Pengantar Psikologi C. G. Jung: Teori-teori dan Teknik Psikologi Kedokteran, diterjemahkan oleh Istiwidayanti, Jakarta: Bhatara Karya Aksara, 1988.

Wiggins-Frame, Marsha, "Spirituality and Religion: Similarities and Differences", In Craig S. Cashwell \& J. Scout Young (eds), Integrating Spirituality and Religion into Counseling: A Guide to Competent Practice. Alexanndria, VA: American Counseling Association. 